\section{Accumulation of Tetrodotoxin by Marine Gastropods*1}

Recently there occurred a food poisoning by one of marine gastropods, the trumpet shell Charonia sauliae, and tetrodotoxin (ITX) was identified as the causative toxin. ${ }^{1}$ TTX was also detected in the ivory shell Babylonia japonica. ${ }^{2,3)}$ However, it was thought that TTX was not originally present in the gastropods but incidentally came from other marine organisms such as the starfish Astropecten polyacanthus ${ }^{4}$ and puffer fishes. ${ }^{3)}$ The present work was conducted to confirm whether marine gastropods can actually take up and accumulate TTX from their baits.

Since the mid-gut glands of 6 specimens of $C$. sauliae caught at Kominato, Chiba Prefecture, in May and October 1981 were non-toxic $(<5 \mathrm{MU} / \mathrm{g})$, this species was judged not to become toxic there. The commercially obtainable ivory shells were also regarded as non-toxic. Therefore, 6 specimens of $C$ sauliae collected at Kominato from March to August 1982 and 22 specimens of the ivory shell (not identified) purchased at Tokyo Central Wholesale Market in December 1982 were used in this study. These specimens were transported alive to our laboratory. Then the C. sauliae specimens were transferred one by one into each aquarium $(29 \times 60 \times 36 \mathrm{~cm})$ containing $60 \mathrm{l}$ of aerated sea water. In the case of the ivory shell, specimens were divided into two groups (14 and 8 specimens) and each group was also transferred into an aquarium. After kept in the aquarium for several days, each specimen or each group was reared using the muscle (toxicity 111-363 MU/g) obtained from 5 specimens of the puffer fish Lagocephalus lunaris lunaris as a feed. The puffer fish muscle was cut into small pieces and fed once a day to each specimen or each group. The weight of feed given daily depended on the appetite of specimens, varying from 2 to $8 \mathrm{~g}$. Throughout the rearing, the puffer fish muscle did not cause any ill effects in the gastropods. At the end of rearing the muscle and mid-gut gland were removed from each specimen or each group and their toxicity was determined by the standard mouse assay. ${ }^{3)}$ One mouse unit (MU) was defined as the amount of toxin required to kill a $20 \mathrm{~g}$ mouse in $30 \mathrm{~min}$.

As shown in Table 1, marine gastropods were found to accumulate TTX from their baits. The mid-gut gland exclusively became toxic while the muscle did not. Although the toxicity of mid-gut gland roughly paralleled the total amount of toxin given, the rates of men (or group) to specimen. It is worth mentioning that the rates of toxin accumulation obtained in this study should be accepted as ninimum values because a part of the toxin contained in the puffer fish muscle must have leaked into the rearing sea water during feeding. The toxin accumulated in the mid-gut gland of $C$. sauliae (No. 6 in Table 1 ) and ivory shell (No. 2 in Table 1) was purified according to the method of YASUMOTO et al. ${ }^{33}$ and identified as TTX by thin layer chromatography and electrophoresis.

Preliminarily, the excretion of TTX from $C$. sauliae was also examined. When a specimen of $C$. sauliae was reared with the puffer fish muscle (total $5196 \mathrm{MU}$ ) for 3 weeks and thereafter with no feed for 10 days, the total toxicity in its mid-gut gland was $1910 \mathrm{MU}$. On the other hand, when another specimen, which had taken up TTX equivalent to $4687 \mathrm{MU}$, was reared with no feed for 4 weeks, its mid-gut gland showed no toxicity. These results suggest that TTX accumulated in C. sauliae can be excreted during rearing of more than 4 weeks without feed. In order to consider a counterplan when marine gastropods accumulate TTX in their bodies, further detailed studies on the excretion of TTX from them are necessary.

This work was partly supported by a grant from the Ministry of Education, Science and Culture of Japan.

Kazuo ShIomi, ${ }^{* 2}$ Eiji TanakA, ${ }^{* 2}$ Hideaki YamaNAKA, ${ }^{* 2}$ and Takeaki KIKUCHI*2

Department of Food Science and Technology, Tokyo University of Fisheries, Konan, Minato, Tokyo 108, Japan.

\section{References}

1) H. Narita, T. Noguchi, J. Maruyama, Y. Ueda, K. Hashimoto, Y. Watanabe, and K. Hma: Bull. Japan. Soc. Sci. Fish., 47, 935-941 (1981).

2) T. Noguchi, J. Maruyama, Y. Ueda, K. HASHIMOTo, and T. HaRAda: Bull. Japan. Soc. Sci. Fish., 47, 909-913 (1981).

3) T. Yasumoto, Y. Oshima, M. Hosaka, and S. MryakoshI: Bull. Japan. Soc. Sci. Fish., 47, 929-934 (1981).

4) T. Noguchi, H. Narita, J. Maruyama, and K. Hashimoto: Bull. Japan. Soc. Sci. Fish., 48, 1173-1177 (1982).

5) Environmental Health Bureau, Ministry of Health and Welfare (ed.): Shokuhin Eisei Kensa Shishin (Shokuhinbetsu), Nippon Shokuhin Eisei Kyokai, Tokyo, 1978, pp. 232-240.

Table 1. Accumulation of TTX by the trumpet shell and ivory shell

\begin{tabular}{|c|c|c|c|c|c|c|c|}
\hline \multirow{2}{*}{ Species } & \multirow{2}{*}{ No. } & \multirow{2}{*}{$\begin{array}{l}\text { Rearing } \\
\text { period } \\
\text { (weeks) }\end{array}$} & \multicolumn{2}{|c|}{ Toxicity $(\mathrm{MU} / \mathrm{g})^{* 1}$} & \multicolumn{2}{|c|}{ Total MU } & \multirow{2}{*}{$\begin{array}{l}\text { Rate of toxin } \\
\text { accumulation } \\
\left(\frac{\mathrm{B}}{\mathrm{A}} \times 100, \%\right)\end{array}$} \\
\hline & & & $\begin{array}{l}\text { Mid-gut } \\
\text { gland }\end{array}$ & Muscle & Given (A) & $\begin{array}{l}\text { Accumulated } \\
(\mathrm{B})^{* 2}\end{array}$ & \\
\hline \multirow{6}{*}{$\begin{array}{l}\text { Trumpet shell } \\
\text { C. sauliae }\end{array}$} & 1 & 1 & 137 & $<5$ & 5214 & 1918 & 36.8 \\
\hline & 2 & 1 & 138 & $<5$ & 6746 & 3643 & 54.0 \\
\hline & 3 & 3 & 184 & $<5$ & 6164 & 3478 & 56.4 \\
\hline & 4 & 3 & 131 & $<5$ & 7742 & 2319 & 30.0 \\
\hline & 5 & 5 & 255 & $<5$ & 13202 & 10965 & 83.1 \\
\hline & 6 & 15 & 735 & $<5$ & 46365 & 22932 & 49.5 \\
\hline \multirow[t]{2}{*}{ Ivory shell } & 1 & 2 & 130 & $<5$ & 9800 & 3484 & 35.6 \\
\hline & 2 & 4 & 66 & $<5$ & 6360 & 1366 & 21.5 \\
\hline
\end{tabular}

* 1 Determined after rearing.

*2 Calculated with mid-gut gland.

(Accepted October 19, 1983)

*1 巻貝類によるテトロドトキシンの梳

*2 塩見一雄・田中栄治・山中英明・菊池武昭：東京水座大学食品生産化学科。 